\title{
Investigation of the Effects of Sun-Dried Apricot with Different Sulphur Levels on Oxidative Stress Markers
}

\author{
Tuğba Raika Kiran ${ }^{1}$, Önder Otlu², Ercan Karabulut ${ }^{3}$, Nermin Özcan $^{1}$ \\ ${ }^{1}$ Iskenderun Technical University Engineering and Nature Science Faculty, Department of Biomedical Engineering, İskenderun, \\ Turkey \\ ${ }^{2}$ Malatya Turgut Ozal University, Faculty of Agriculture, Department of Soil Science and Plant Nutrition, Malatya, Turkey \\ ${ }^{3}$ Ankara Yildirim Beyazit University, Medical Faculty, Department of Medical Pharmacology, Ankara Turkey
}

Received: 02 December 2019, Accepted: 09 December 2019, Published online: 31 December 2019

(C) Ordu University Institute of Health Sciences, Turkey, 2019

\begin{abstract}
Objective: Apricots are mostly consumed in dried form worldwide. Studies are reporting some allergic effects of dried apricot because of its content of sulfur, which is used in the drying process. Therefore, sulphur content has been limited by many countries. This study was conducted to determine the effects of sun-dried apricots with different sulfur contents on nitric oxide (NO), malondialdehyde (MDA) and glutathione (GSH) that are among the markers of oxidative stress.

Methods: A total of 84 Wistar albino rats were divided into groups as control, sun-dried apricot, 1000, 2000, 3000 and $4000 \mathrm{ppm}$ sulfured groups. At the end of the 12th week, rats were sacrificed under general anesthesia. NO, MDA and GSH levels were studied at the end of the experiment from the ovarian and testicular tissues of the rats.

Results: No statistically significant differences were found among the groups in terms of NO, MDA and GSH in the ovarian and testicular tissues removed from the rats

Conclusion: We claim that sulfur amount of dried apricots is not affect on reproductive system. This study is guiding further studies that will be conducted against the restrictions in sulfur used in the drying process of dried apricots, which is economically very important for dried fruits sector.
\end{abstract}

Key words: Sulphur dried apricot, Oxidative stress, Rat, Ovary, Testes

Suggested Citation: Kiran TR, Otlu O, Karabulut E, Ozcan N. Investigation of the effects of sun-dried apricot with different sulfur levels on oxidative stress markers. Middle Black Sea Journal of Health Science, 2019; 5(3):239-245

\section{Address for correspondence /reprints:}

Tugba Raika Kiran

Telephone number: +90 (532) 3267452

E-mail: traika.kiran@iste.edu.tr

DOI: $10.19127 / \mathrm{mbsjohs} .654240$

\section{Introduction}

Today studies conducted on herbals that can potentially replace medical drugs are important because of the wide range of side effects. Apricot is one of the fruits investigated for alternative or complementary treatments of various diseases. Apricot, which belongs to the Rosaceae family is a medical plant with reported contents polyphenol, polysaccharides, fatty acid and carcinogenic glycosylase, vitamin A and vitamin C. Apricot also contains basic flavonoids such as chlorogenic acids, catechins and quercetin (Chan et al., 2008). Parlakpinar et al. found that feeding with apricots reduces ischemia-reperfusion damage in rats (Parlakpinar et al., 2009). Antimicrobial, cardioprotective, antimutagenic and antiinflammatory activities and hepatoprotective effects 
of apricot have been reported (Raj et al., 2016; Ruiz et al., 2005; Y1lmaz et al., 2015).

Apricot is most commonly used in dried form. Philippi reported that nutrients, and thus calorie concentration are higher in dried apricot (Zamboni et al., 2011). Dried apricot is one of the important traditional export products of the dried fruit sector, and Turkey is the leading country of fresh and dried apricots production worldwide. In Malatya province, which meets more than half of the apricot production of Turkey, the production is more commonly wide with dried apricots and $90 \%$ to $95 \%$ of dried apricots are exported (TCEB, 2017).

The drying process aims to prolong shelf life by reducing physical, chemical, microbiological and enzymatic reaction rates through the removal of the water content, to decrease costs of packaging, warehouse and transportation, and to protect nutritional value (Jayaraman and Das Gupta, 1992). Another drying method, drying by sulphurization is preferred to protect the natural color of apricots and to prolong shelf life (Bayram et al., 2007).

It has been proven that sulfur dioxide $\left(\mathrm{SO}_{2}\right)$ which is used in the drying process may lead to oxidative stress and DNA damage in various organs (Meng and Liu, 2007). Also, it has been reported that $\mathrm{SO}_{2}$ /sulfide may cause biological damage by commencing peroxidation of polyunsaturated fatty acids (PUFA), DNA synthesis accompanied by mutations, cellular division and inhibition of mitosis (Shapiro, 1977). Again, it has been underlined that sulfide-based preservatives, especially in apricots and some dried fruits, may cause allergic reactions or asthma exacerbations in susceptible persons.

Based on these studies, it has been proposed that the content of the sulfur used in drying foods should be reduced. The legal limit of $\mathrm{SO}_{2}$ content in dried apricot has been accepted as $2000 \mathrm{mg} / \mathrm{kg}$ in European Union, $2500 \mathrm{mg} / \mathrm{kg}$ in Canada and 3000 $\mathrm{mg} / \mathrm{kg}$ in the United States (Asma, 2007; Codex, 1981).

Estimated amounts of daily intake of inorganic food additives per person are reported $1.629 \mathrm{mg}$ (as $50 \mathrm{~kg}$ body weight) for sulfur dioxide (Ishiwata et al., 1998). It is important to establish the balance between sulfur level used in the dried fruits to protect natural color and prolong shelf life, and biochemical reactions caused by this agent. The number of studies in the literature on this issue is not sufficient. Because oxidative stress that has been proposed to be increased by sulfur, which is used in the drying process of apricots plays an important role in the pathophysiology of many diseases, we thought that investigation of the effects of sulfur levels used in the drying process of apricot on the markers of oxidative stress will clarify this issue. Therefore, based on this information, in this study, we aimed to investigate the effects of sundried apricot with various sulfur levels on NO, MDA and GSH that are among the markers of oxidative stress.

\section{Methods}

\section{Chemicals, animals and diets}

A total of 84 Wistar albino rats used in this study (42 female and 42 male) were supplied from the Inonu University Experimental Animals Reproduction and Research Center. The principles of the Inonu University Experimental Animals Ethics Committee was followed during the study. 18 -weeks old rats weighing $205 \pm 13 \mathrm{~g}$ were kept in standard cages until the day of the experiment. Throughout the experiment, the drinking water was changed daily, and the standard cage cleaning was done. The rats were housed in rooms with air conditioner in $24-27{ }^{\circ} \mathrm{C}$ room temperature with 12 hours of light and 12 hours of dark.

Female and male rats were kept in separate cages and divided into 6 groups. Each group included 7 rats to provide statistical significance. The rats were distributed into the cage to provide a maximum of two rats in each cage to provide homogenous feed intake. Only control groups were fed with commercial pellet feed.

The rats used in this study were divided into groups as follows.

Group 1: Control Group ( $\mathrm{n}=14 ; 7$ males, 7 female): Rats were fed with commercial pellet feed and sacrificed in the 12th-week.

Group 2: Sun-Dried Apricot Group ( $\mathrm{n}=14 ; 7$ males, 7 female): Rats were fed with feed prepared with (w/w) 10\% dried apricot ad libitum and sacrificed in the 12th-week

Group 3: 1000 ppm Sulfured Apricot Group ( $n=14 ; 7$ males, 7 female): Rats were fed with feed prepared with $(\mathrm{w} / \mathrm{w}) 10 \%$ dried apricots containing $1000 \mathrm{ppm}$ sulfur ad libitum and sacrificed in the 12th-week.

Group 4: 2000 ppm Sulfured Apricot Group ( $\mathrm{n}=14 ; 7$ males, 7 female): Rats were fed with feed prepared with $(\mathrm{w} / \mathrm{w}) 10 \%$ dried apricots containing $2000 \mathrm{ppm}$ sulfur ad libitum and sacrificed in the 12th-week.

Group 5: 3000 ppm Sulfured Apricot Group $(\mathrm{n}=14 ; 7$ males, 7 female): Rats were fed with feed prepared with $(\mathrm{w} / \mathrm{w}) 10 \%$ dried apricots containing $3000 \mathrm{ppm}$ sulfur ad libitum and sacrificed in the 12th-week. 
Group 6: 4000 ppm Sulfured Apricot Group ( $\mathrm{n}=14 ; 7$ males, 7 female): Rats were fed with feed prepared with $(\mathrm{w} / \mathrm{w}) 10 \%$ dried apricots containing $4000 \mathrm{ppm}$ sulfur ad libitum and sacrificed in the 12th-week.

\section{Determination of Sulfur Amount of Apricots}

The sulfur amount in the apricots was determined according to the Turkish Standard no:8131. The apricots were classified according to the sulfur content, ground and stored at $+4^{\circ} \mathrm{C}$ in portions.

Preparation of Pellets Containing Sun-Dried Apricots and Sulfur-Containing Apricots

During the experiments, sun-dried and sulfurcontaining apricots were mixed with pellets at $10 \%$. In order to minimize the decrease of sulfur ratio due to waiting for the prepared pellets, the pellets were prepared as $3 \mathrm{~kg}$ at every turn. For this purpose, 300 $\mathrm{g}$ of the apricots that were previously ground and kept at $+4{ }^{\circ} \mathrm{C}$ were weighed and powder pellet was added until $3 \mathrm{~kg}$ pellet was obtained (approximately $2700 \mathrm{~g}$ ). Some water was added to the mixture, which was then worked until it became thoroughly homogenized and then made pellet again utilizing a pellet machine.

Obtaining Ovarian and Testicular Tissues and Preparing for Analyzes

At the end of the 12th-week, rats were sacrificed under general anesthesia. Ovarian and testicular tissues from rats were wrapped in aluminum foil and stored at $-70{ }^{\circ} \mathrm{C}$ in deep freezing until the day when biochemical tests were to be carried out.

\section{Tissue Homogenization and Tampons}

Tissues weighed approximately $200 \mathrm{mg}$ were homogenized at a rate of $16000 \mathrm{rpm}$ by adding $2 \mathrm{~mL}$ of Tris - $\mathrm{HCl}$ tampon (pH: 7.0). After homogenization, the tubes were centrifuged at 4000 rpm for 10 minutes at $+4{ }^{\circ} \mathrm{C}$. Supernatants formed after centrifugation were taken into Eppendorf tubes and kept in the freezer until the day of operation. All chemicals and reagents used were of analytical grade and were purchased from Sigma-Aldrich (Saint-Quentin-Fallavier, France). Bidistilled water was used in all the studies.

\section{Estimation of Oxidative Stress Markers}

\section{Measurement of Nitric Oxide}

NO formed in the medium by nitric oxide synthase (NOS) activity was reduced from nitrate to nitrite with cadmium granules, and the colored compound formed following reaction with Griess reactive was measured at $545 \mathrm{~nm}$ with a spectrophotometer (Cortas and Wakid, 1990).

\section{Measurement of Lipid Peroxidation}

The measurement of MDA, which is a product of lipid peroxidation was performed using the Uchiyama and Mihara method (Mihara and Uchiyama, 1978). This method is based on spectrophotometric evaluation of the absorbance of pink-red color formed as a reaction of tissue MDA with 2-Thiobarbituric acid (TBA) at $95^{\circ} \mathrm{C}$. For the standard measurement, the standard graphic was drawn with solutions prepared by serial dilution of the $10 \mathrm{mmol} / \mathrm{L} \mathrm{NaNO}_{3}$ stock solution $(5-200 \mu \mathrm{M})$.

\section{Measurement of Reduced Glutathione}

This method is based on spectrophotometric evaluation of the absorbance of yellow product formed as a reaction of sulfhydryl groups found in glutathione with Ellman's reagent 5,5'-Dithiobis (2nitrobenzoic acid) (DTNB), at $412 \mathrm{~nm}$ (Tietze F, 1994).

\section{Statistical analysis}

In the statistical analysis of the data obtained from this study, normality of the variables was tested with the Shapiro-Wilks method and it was found that the variables were non-normally distributed. Thus, the variables were evaluated using non-parametric tests. Kruskal Wallis test was used in the comparison of groups and MannWhitney $U$ test for paired comparisons. $p<0.05$ values were considered statistically significant. The statistical analysis was performed using IBM SPSS Statistics version 23.0 package software.

\section{Results}

A Total of 84 Wistar albino rats were included in the study with 42 being female and 42 males. The mean age of the rats was 18 weeks and the mean weight was $205 \pm 13 \mathrm{~g}$. Ovarian and testicular tissues obtained from the sacrificed rats at the end of the 12-week experimental period were subjected to biochemical analysis with the spectrophotometric method.

When oxidative stress markers were examined in the ovarian tissues obtained from the female rats 
were examined; median $\mathrm{NO}$ values were found as $38.95 \mu \mathrm{mol} / \mathrm{g}$ in Group 1, $41.51 \mu \mathrm{mol} / \mathrm{g}$ in Group 2, $44.25 \mu \mathrm{mol} / \mathrm{g}$ in Group 3, $37.89 \mu \mathrm{mol} / \mathrm{g}$ in Group 4, $44.70 \mu \mathrm{mol} / \mathrm{g}$ in Group 5 and $43.33 \mu \mathrm{mol} / \mathrm{g}$ in Group 6. In the Kruskal Wallis test, no significant difference was found among the groups in terms of NO values $(\mathrm{p}=0.733)$ (Figure 1$)$.

Median MDA values were found as 43.43 $\mathrm{nmol} / \mathrm{g}$ in Group 1, $41.14 \mathrm{nmol} / \mathrm{g}$ in Group 2, 43.18 $\mathrm{nmol} / \mathrm{g}$ in Group 3, $42.02 \mathrm{nmol} / \mathrm{g}$ in Group 4, 44.42 $\mathrm{nmol} / \mathrm{g}$ in Group 5 and $43.37 \mathrm{nmol} / \mathrm{g}$ in Group 6. No statistically significant difference was found among the groups in terms of MDA values $(\mathrm{p}=0.975)$ (Figure 1).

Median GSH values were found as $39.82 \mu \mathrm{mol} / \mathrm{g}$ in Group 1, $38.34 \mu \mathrm{mol} / \mathrm{g}$ in Group 2, $36.19 \mu \mathrm{mol} / \mathrm{g}$ in Group 3, $32.85 \mu \mathrm{mol} / \mathrm{g}$ in Group 4, $31.98 \mu \mathrm{mol} / \mathrm{g}$ in Group 5 and $31.19 \mu \mathrm{mol} / \mathrm{g}$ in Group 6. No statistically significant difference was found among the groups in terms of GSH values $(\mathrm{p}=0.659)$ (Figure 1).

When oxidative stress markers were examined in the testicular tissues obtained from the male rats were examined; median $\mathrm{NO}$ values were found as $35.99 \mu \mathrm{mol} / \mathrm{g}, 40.87 \mu \mathrm{mol} / \mathrm{g}$ in Group 2, 43.10 $\mu \mathrm{mol} / \mathrm{g}$ in Group 3, $41.72 \mu \mathrm{mol} / \mathrm{g}$ in Group 4, 44.70 $\mu \mathrm{mol} / \mathrm{g}$ in Group 5 and $42.42 \mu \mathrm{mol} / \mathrm{g}$ in Group 6. In the Kruskal Wallis test, no significant difference was found among the groups in terms of $\mathrm{NO}$ values $(\mathrm{p}=0.365)$ (Figure 2).

Median MDA values were found as 45.65 $\mathrm{nmol} / \mathrm{g}$ in Group 1, $43.34 \mathrm{nmol} / \mathrm{g}$ in Group 2, 45.93 $\mathrm{nmol} / \mathrm{g}$ in Group 3, $43.78 \mathrm{nmol} / \mathrm{g}$ in Group 4, 45.10 $\mathrm{nmol} / \mathrm{g}$ in Group 5 and $44.08 \mathrm{nmol} / \mathrm{g}$ in Group 6. No statistically significant difference was found among the groups in terms of MDA values $(\mathrm{p}=0.679)$ (Figure 2).

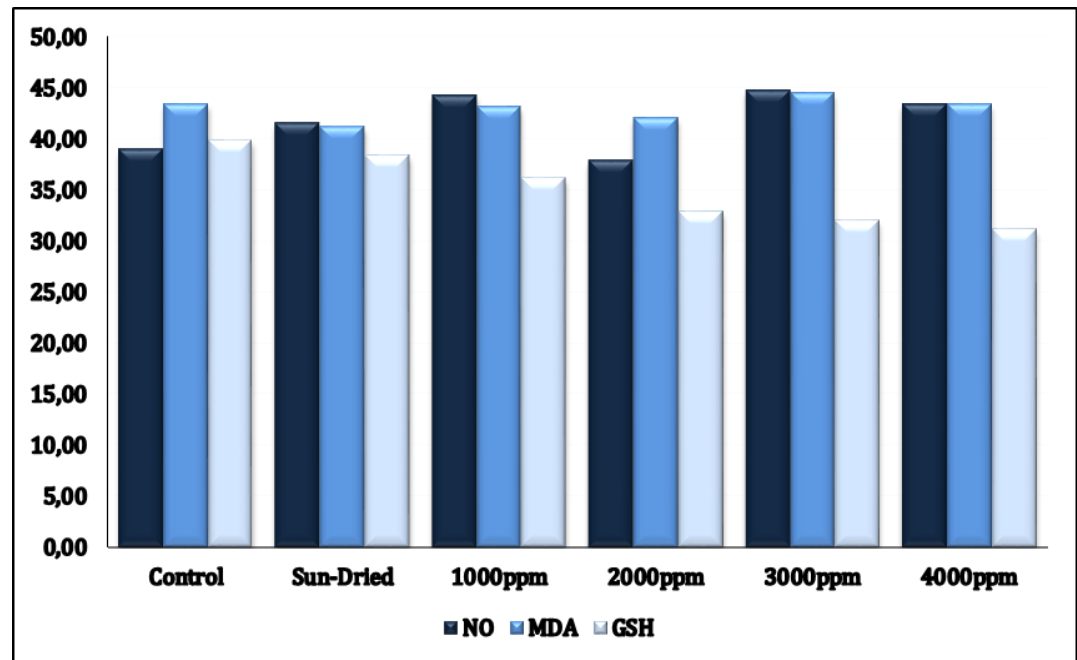

Figure 1. NO, MDA and GSH values in ovarian tissues obtained from the groups.

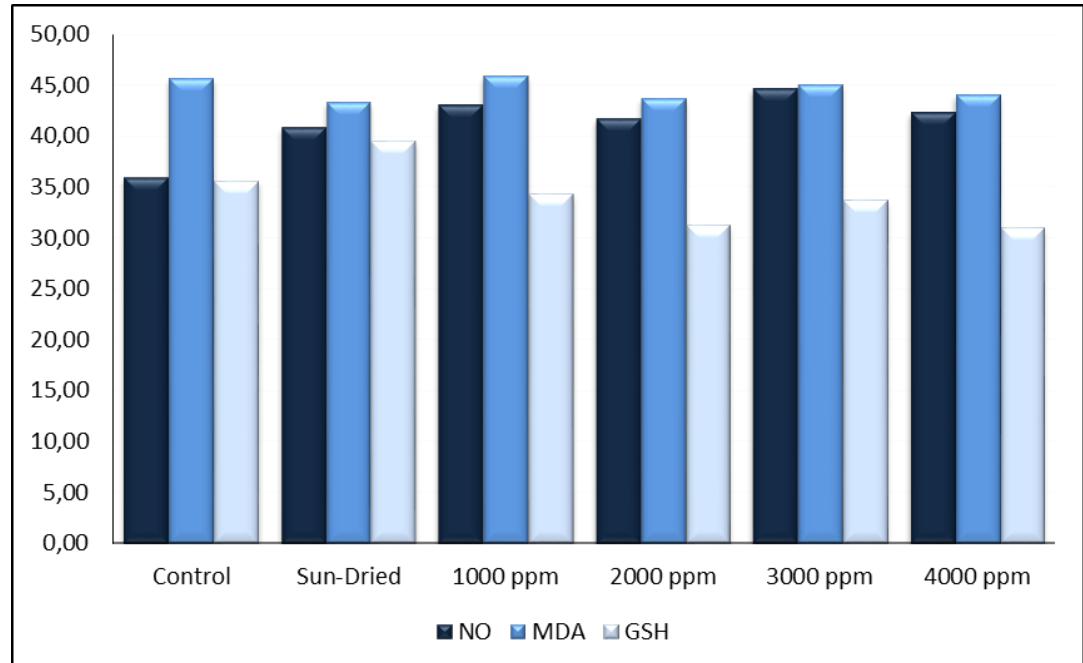

Figure 2. NO, MDA and GSH values in testicular tissues obtained from the groups 
Table 1. Comparison of oxidative stress markers.

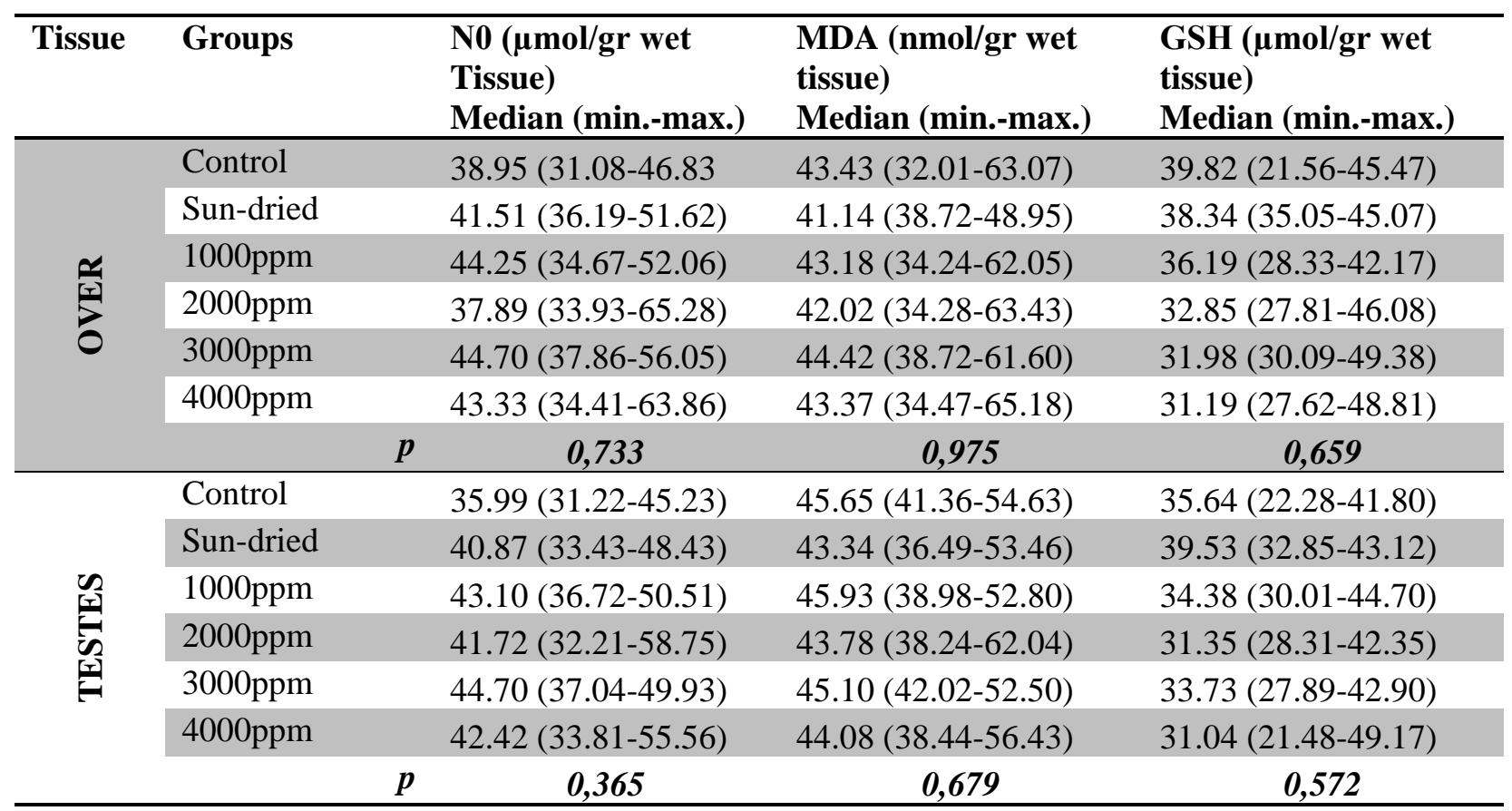

Median GSH values were found as $35.64 \mu \mathrm{mol} / \mathrm{g}$ in Group 1, $39.53 \mu \mathrm{mol} / \mathrm{g}$ in Group 2, $34.38 \mu \mathrm{mol} / \mathrm{g}$ in Group 3, $31.35 \mu \mathrm{mol} / \mathrm{g}$ in Group 4, $33.73 \mu \mathrm{mol} / \mathrm{g}$ in Group 5 and $31.04 \mu \mathrm{mol} / \mathrm{g}$ in Group 6. No statistically significant difference was found among the groups in terms of GSH values $(p=0.572)$ (Figure 2). A comparison of oxidative stress parameters within groups was given in Table1.

\section{Discussion}

Apricot consumption is predominantly in dried form worldwide. Sulphurization process is performed in drying apricots to provide fruit supply and prolong shelf life. According to the results of the study by Davis et al., dried fruits suppliers should target $3000 \mathrm{ppm} \mathrm{SO}_{2}$ content for an acceptable fruit supply from one season to another (Davis et al., 1973).

On the other hand, the sulphurization process has been reported to affect many body mechanisms, especially oxidative stress. Lizada et al. demonstrated that sulfur initiates linoleic acid peroxidation through a free radical mechanism (Lizada and Yang, 1981). It has been shown that sulfides lead some health problems such as asthmatic reactions when inhaled or intaken to the body in susceptible persons (Miranda et al., 2009). Besides, sulfur causes allergic reactions in susceptible people. These allergic reactions are in a wide range from mild reactions such as urticaria to severe reactions such as difficulty in breathing and potential anaphylactic shock. Also, low blood pressure, abdominal pain and diarrhea can be seen in susceptible persons.

Therefore, the sulfur content in dried fruits, including apricots has been restricted in many regions of the world. Sulfur content in dried fruits has been limited between 1000-3000 ppm in many countries. While the Australia government has a limited amount of sulfur in foods with $3000 \mathrm{ppm}$, England has determined this limit as 2000 ppm. In Turkey, which is among the largest apricots suppliers worldwide, one of the most important problems for the dried fruit sector is a limited amount of sulfur in terms of export.

According to the CODEX General Standard for Food Additives, the maximum sulfur level allowed for dried apricot is $2000 \mathrm{ppm}$. This rate is also 2000 ppm in the Europe Union directive 95/2/EC (Codex). The amount of sulfur and duration of sulphurization are the effective parameters on sulfur content due to these limitations (Turkyılmaz et al. 2013). Research on alternative drying methods is continuing.

On the other hand, studies are reporting that a large part of sulfur absorbed during sulphurization losses during drying and again there is a slow loss in sulfur content during shelf life (McBean, 1967).

There is no study in the literature investigating the effects of sun-dried apricots with various sulfur levels on body mechanisms. There are only few articles that investigate the effects of sulfur exposure in workers. Koksal et al. found significant decrements in FEV1, FEV1/FVC\%, and FEF 25 - 
$75 \%$ in study of pulmonary function in 69 workers revealing that $\mathrm{SO}_{2}$ exposure on the airways of the workers gas may be the causative agent of asthmalike syndrome (Koksal et al., 2003). In a vivo study by Koksal et al., found that cytokines such as TNFa, IL-1h, IL-6, IL-8 and NO may play a role in the pathogenesis of $\mathrm{SO}_{2}$-induced bronchoconstriction in the asthma-like syndrome caused by high concentration of $\mathrm{SO}_{2}$ exposure during apricot sulfurization processes (Koksal et al., 2003a). Unlikely these results, in an in vivo study Knorst et al. found that high amount of sulfur dioxide induced a significant decrease in spontaneous and lipopolysaccharide-stimulated tumor necrosis factor- $\alpha$ and lipopolysaccharide-stimulated interleukin-1 $\beta$ release (Knorst et al., 1996) But in our study, no statistically significant differences were found between NO, MDA and GSH levels that are among oxidative stress markers in the ovarian and testicular rats that were fed with non-sulfured and 1000, 2000, 3000 and 4000 ppm sulfured sundried apricots over 12 weeks (Table1). Given significant economical losses about dried apricots supply and export, our results indicate an important lack of studies to be conducted on this issue. We could not compare our results with other studies since there is no study on the same issue.

As a result, we haven't seen any significant changes, even in $4000 \mathrm{ppm}$ group, in oxidative stress parameters of rats' ovarian and testicular tissues. We claim that sulfur amount of dried apricots is not affect on reproductive system. This study is guiding in the literature against the restrictions in the drying process of dried apricots, which is economically very important for the dried fruits sector. We believe that the results of our study are encouraging for furthermore comprehensive studies that will be performed in the future.

Acknowledgment: The authors thank to Prof. Dr. Aysun Bay Karabulut for valuable comments on the manuscript.
Ethics Committee Approval: Ethics committee approval was received for this study from Clinical Research Ethics Committee of Inonu University (2016/A-02).

Peer-review: Externally peer-reviewed.

Author Contributions: Externally peer-reviewed. Author Contributions: Concept - TRK, OO, EK Design TRK, EK Supervision TRK, EK, OO; Materials -TRK, EK, OO; Data Collection and/or Processing - TRK, OO, EK, NO; Analysis and/or Interpretation- TRK, OO, EK, NO; Literature Review- TRK, OO, EK, NO; Writing- TRK, OO, EK, NO; Critical Review - TRK, OO, EK, NO.

Conflict of Interest: No conflict of interest was declared by the authors.

Financial Disclosure: The authors declared that this study hasn't received no financial support.

\section{References}

Asma BM. Malatya: World's capital of apricot culture. Chronica Horticulturae. 2007; 47: 20-4.

Bayram MA, Kan T, Birhanlı O. Characterization of Promising Apricot (Prunus armeniaca L.) Genetic Resources in Malatya. Genetic Resources and Crop Evolution. 2007; 54: 20512.

Chan YH, Lau KK, Yiu KH, Li SW, Chan HT, Fong DY, Tam S, Lau CP, Tse HF. Reduction of Creactive protein with isoflavone supplement reverses endothelial dysfunction in patients with ischaemic stroke. European Heart Journal. 2008; 29: 2800-7.

Codex Alimentarius International Food Standards. Codex Standard for Dried Apricots. Codex Stan. (serial online) 1981; 130: 1-5. Available from: URL: $\quad$ http:/www.fao.org/fao-whocodexalimentarius/codex-texts/allstandards/en/.

Cortas NK, Wakid NW. Determination of inorganic nitrate in serum and urine by a kinetic cadmium reduction method. Clinical Chemistry. 1990; 36: 1440-3.

Davis EG, McBean DMG, Roonele ML, Gipps PG. Mechanisms of sulphur dioxide loss from dried fruits in flexible films. International Journal of Food Science and Technology. 1973; 8: 391405. 
Ishiwata H, Nishijima M, Fukasawa Y, Ito Y, Yamada T. Evaluation of the inorganic food additive (nitrite, nitrate and sulfur dioxide) content of foods and estimation of daily intake based on the results of official inspection in Japan in Fiscal Year 1994. J. Food Hygiene and Safety Science.1998; 39: 78-88.

Jayaraman KS, Das Gupta DK. Dehydration of fruits and vegetables-Recent developments in principles and techniques. Drying Technology: An International Journal. 1992; 10: 1-50.

Knorst MM, Kienast K, Quernheim JM, Ferlinz R. Effect of Sulfur Dioxide on Cytokine Production of Human Alveolar Macrophages in Vitro. Archives of Environmental Health: An International Journal. 1996; 51(2): 150-156.

Koksal N, Hasanoglu HC, Gokirmak M, Yildirim Z, Gultek A. Apricot Sulfurization: An Occupation That Induces an Asthma-Like Syndrome in Agricultural Environments. American Journal of Industrial Medicine. 2003; 43: 447-53.

Koksal N, Yıldırım Z, Gokırmak M, Hasanoğlu HC, Mehmet N, Avc1 H. The role of nitric oxide and cytokines in asthma-like syndrome induced by sulfur dioxide exposure in agricultural environment. Clinica Chimica Acta. 2003a; 336: 115-22.

Lizada MCC, Yang SF. Sulfite-lnduced Lipid Peroxidation. Lipids. 1981; 16: 189-94.

McBean, DMcG. Levels of free and combined sulfur dioxide in fruits during sulfuring and drying. Food Technology. 1967; 21 (10): 112-6.

Meng Z, Liu Y. Cell morphological ultrastructural changes in various organs from mice exposed by inhalation to sulfur dioxide. Inhalation Toxicology. 2007; 19: 543-51.

Mihara M, Uchiyama M. Determination of malonaldehyde precursor in tissues by thiobarbituric acid test. Analytical Biochemistry. 1978; 86: 271-8.

Miranda G, Berna A, Salazar D, Mulet A. Sulphur dioxide evolution during apricot storage. Food Science and Technology. 2009; 42: 531-3.

Parlakpinar H, Olmez E, Acet A, Ozturk F, Tasdemir S, Ates B, et al. Beneficial effects of apricot-feeding on myocardial ischemiareperfusion injury in rats. Food and Chemical Toxicology. 2009; 47: 802-8.

Raj V, Mishra AK, Mishra A, Najam AK. Hepatoprotective effect of Prunus armeniaca L. (Apricot) leaf extracts on Paracetamol induced liver damage in Wistar rats. Pharmacognosy Journal. 2016; 8: 154-8.
Ruiz D, Egea J, Gil MI, Tomás-Barberán FA. Characterization and quantitation of phenolic compounds in new apricot (Prunus armeniaca L.) varieties. Journal of Agricultural Food Chemistry. 2005; 53: 9544-52.

Shapiro R. Genetic effects of Bisulfite (Sulfur dioxide). Mutation Research.1977; 39: 149-76.

Tietze F. Enzymic method for quantitative determination of nanogram amounts of total and oxidized glutathione: applications to mammalian blood and other tissues. Anal Biochem. 1969; 27: 502-22.

Turkyılmaz M, Tagi S, Ozkan M. Changes in chemical and microbial qualities of dried apricots containing sulphur dioxide at different levels during storage. Food and Bioprocess Technology. 2013; 6: 1526-38.

Türkiye Cumhuriyeti Ekonomi Bakanlığı (TCEB). Sektör Raporları, Kuru Kayısı. 2017; 1-3. Available from: URL: https:/www.ticaret.gov.tr/data/5b8700a513b876 1450e18d81/Kuru_Kayisi.pdf.

Y1lmaz I, Cetin A, Bilgic Y. Hepatoprotective Effects of Apricot against AcetaminophenInduced Acute Hepatotoxicity in Rats. American Journal of Pharmacological Sciences. 2015; 3(2): 44-8.

Zamboni CB, Medeiros IMMA, Medeiros JAG. Analysis of sulphur in dried fruits using NAA. International Nuclear Atlantic Conference (INAC); October 24-28; Belo Horizonte, Brazil: p. 1-6. 2011. 